\title{
PERENCANAAN SPASIAL DAN STRATEGI PENINGKATAN HASIL PRODUKSI BENIH JAGUNG HIBRIDA DI KABUPATEN BONE
}

\section{Spatial Planning and Strategy for Improving The Production of Hybrid Corn Seeds In Bone District}

\author{
Sumarni Panikkai ${ }^{{ }^{*}}$, Wahyu Hidayat ${ }^{2}$, Bahtiar $^{3}$ \\ 1,3 Balai Penelitian Tanaman Serealia \\ ${ }^{2}$ Universitas Muhammadiyah Bulukumba
}

*Email: marnibalitsereal@gmail.com

\begin{abstract}
Bone Regency has great potential as a pioneer of corn seed producers, especially hybrid corn in eastern Indonesia. This potential is a regional advantage that will further develop if it utilizes natural resources and the environment in accordance with the conditions of corn farming. Corn is a food crop commodity that has a role in the development of Indonesia's agricultural economy because corn commodity has a multipurpose function (4F), namely for food (food), feed (feed), fuel (fuel), and industrial raw materials (fiber). Therefore, to achieve these conditions, information is needed related to regional development planning so that it is expected to create a sustainable agricultural development. The purpose of this study is to provide spatial data for locations that are suitable for corn plant development planning and information on strategies for increasing yields of corn crops. The specific objectives of the study are: 1. Analyze land suitability based on the carrying capacity of the land (capability of kahan) for planning corn development. 2. Creating a strategy to increase production results. The method used in this research is land carrying capacity and descriptive. The research locations were Ajangale District, Amali District and Dua Boccoe District, Bone Regency. The results of this study, there are 42 villages that are suitable for the development of corn plants that are presented in the land suitability map based on the carrying capacity of the land and the Regional Spatial Plan (RTRW). Strategy to increase yields of maize production by piloting a Farmer-based Corporation project.
\end{abstract}

Keywords: Land Suitability, Agricultural Cultivation, Corn, Bone Regency

\begin{abstract}
ABSTRAK
Kabupaten Bone memiliki potensi besar sebagai pioner produsen benih jagung khususnya jagung hibrida di kawasan timur indonesia. Potensi ini merupakan keunggulan wilayah yang akan semakin berkembang apabila memanfaatkan sumberdaya alam dan lingkungan sesuai dengan kondisi pertanian tanaman jagung. Jagung merupakan komoditas tanaman pangan yang mempunyai peran dalam pembangunan ekonomi pertanian indonesia karena komoditas jagung mempunyai fungsi multiguna (4F), yaitu untuk pangan (food), pakan (feed), bahan bakar (fuel), dan bahan baku industri (fiber). Oleh sebab itu, untuk mencapai kondisi tersebut, di butuhkan informasi terkait perencanaan pengembangan wilayah sehingga di harapkan tercipta suatu pembangunan wilayah pertanian yang berkelanjutan. Tujuan dari penelitian ini adalah untuk menyediakan data spasial untuk lokasi yang sesuai perencanaan pengembangan tanaman jagung dan informasi strategi peningkatan hasil produksi tanaman jagung. Adapun tujuan khusus penelitian yaitu:1. Menganalisis kesesuaian lahan berdasarkan daya dukung lahan (kemampuan kahan) untuk perencanaan pengembangan tanaman jagung. 2. Membuat Strategi peningkatan hasil produksi. Metode yang digunakan dalam penelitian ini yaitu daya dukung lahan dan deskriptif. Lokasi penelitian yaitu Kecamatan Ajangale, Kecamatan Amali dan Kecamatan Dua Boccoe Kabupaten Bone. Hasil penelitian ini, terdapat 42 desa yang sesuai untuk pengembangan tanaman jagung yang disajikan dalam peta kesesuaian lahan berdasarkan daya dukung lahan dan Rencana Tata Ruang Wilayah (RTRW). Strategi peningkatan hasil produksi tanaman jagung dengan cara pilot proyek berbasis Korporasi Petani.
\end{abstract}

Kata Kunci: Kesesuaian Lahan, Budidaya Pertanian, Jagung, Kabupaten Bone 


\section{PENDAHULUAN}

Indonesia merupakan negara agraris yang memiliki potensi sangat besar dalam meningkatkan produksi hasil pertanian. Pengembangan sektor pertanian tanaman pangan merupakan salah satu strategi kunci dalam memacu pertumbuhan ekonomi suatu wilayah. Kabupaten Bone dengan karakteristik perekonomian yang didominasi oleh sektor pertanian yang meliputi tanaman pangan, holtikultura dan perkebunan. Peranan sektor pertanian terhadap perekonomian Kabupaten Bone pada tahun 2018 sangat besar dibanding dengan sektor-sektor lain yakni sebesar 49,43\% (BPS Bone, 2018).

Kabupaten Bone memiliki potensi besar sebagai pioner produsen benih jagung khususnya jagung hibrida di kawasan timur indonesia. Potensi ini merupakan keunggulan wilayah yang akan semakin berkembang apabila memanfaatkan sumberdaya alam dan lingkungan sesuai dengan kondisi pertanian tanaman jagung. Jagung merupakan komoditas tanaman pangan yang mempunyai peran dalam pembangunan ekonomi pertanian indonesia. Permintaan jagung terus mengalami peningkatan berbanding lurus dengan pertumbuhan penduduk sebagai dampak dari peningkatan kebutuhan pangan, konsumsi protein hewani dan energi.
Menurut Panikkai (2017) bahwa komoditas jagung mempunyai fungsi multiguna (4F), yaitu untuk pangan (food), pakan (feed), bahan bakar (fuel), dan bahan baku industri (fiber). Oleh sebab itu, untuk mencapai kondisi tersebut, di butuhkan informasi terkait perencanaan pengembangan wilayah sehingga di harapkan tercipta suatu pembangunan wilayah pertanian yang berkelanjutan.

Tujuan dari penelitian ini adalah untuk menyediakan data spasial untuk lokasi yang sesuai perencanaan pengembangan tanaman jagung dan informasi strategi peningkatan hasil produksi tanaman jagung. Adapun tujuan khusus penelitian yaitu: 1. Menganalisis kesesuaian lahan berdasarkan daya dukung lahan (kemampuan kahan) untuk perencanaan pengembangan tanaman jagung. 2. Membuat Strategi peningkatan hasil produksi tanaman jagung.

\section{METODE}

Penelitian ini dilaksanakan wilayah di Kecamatan Dua Boccoe, Kecamatan Ajangale dan Kecamatan Amali Kabupaten Bone Provinsi Sulawesi Selatan (Gambar 1) pada bulan Juli 2019 sampai bulan Oktober 2019.

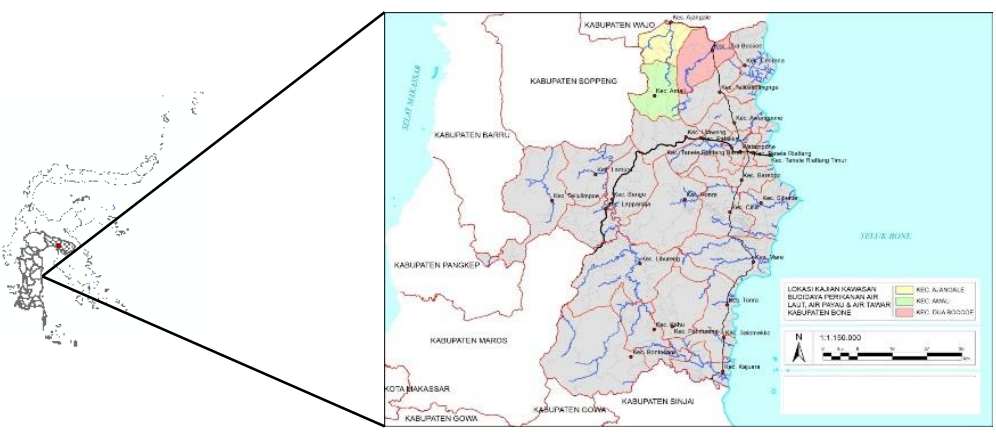

Gambar 1 Peta lokasi penelitian

Data yang digunakan yaitu data sekunder dan primer. Jenis data sekunder; Kabupaten Bone dalam angka Tahun 2018, Kecamatan Ajangale, Amali, Dua Boccoe dalam angka Tahun 2018, Dokumen RTRW Kabupaten Bone tahun 20122032. Jenis data primer yang digunakan adalah jenis data kualitatif yaitu keterangan naratif semata. Data sekunder yang digunakan dalam penelitian ini bersumber dari beberapa instasi pemerintahan maupun non-pemerintahan. Data primer yang digunakan dalam penelitian ini bersumber dari data yang dapat diperoleh dengan wawancara dari sejumlah informan dan hasil observasi. Alat yang digunakan adalah ArcGIS 10.3, dan Microsoft Office Excel 2007.

\section{Analisis Kemampuan Lahan}

Klasifikasi kemampuan lahan merupakan klasifikasi potensi lahan untuk penggunaan berbagai sistem pertanian secara umum tanpa menjelaskan peruntukkan untuk jenis tanaman tertentu maupun tindakan-tindakan pengelolaannya. Tujuannya adalah untuk mengelompokkan lahan yang dapat diusahakan bagi pertanian berdasarkan potensi dan pembatasnya agar dapat berproduksi secara berkesinambungan. Klasifikasi penggunaan lahan merupakan sistem klasifikasi yang dikembangkan oleh Hockensmith dan Steele pada tahun 1943 yang kemudian dimodifikasi oleh Klingebel dan Montgomery (1961; 2002), seperti yang tertuang dalam Agriculture Handbook No. 210. Dalam sistem klasifikasi ini lahan dikelompokkan ke 
dalam tiga kategori, yaitu kelas, subkelas, dan satuan (unit) kemampuan atau pengelolaan (Hardjowigeno dan Widiatmaka, 2001).

Kemampuan lahan merupakan pencerminan kapasitas fisik lingkungan yang dicerminkan oleh keadaan topografi, tanah, hidrologi, dan iklim, serta dinamika yang terjadi khususnya erosi, banjir dan lainnya. Menurut Handayani et al (2005) Data spasial seperti topografi, tanah dapat di analisis secara spasial . Kombinasi karakter sifat fisik statis dan dinamik dipakai untuk menentukan kelas kemampuan lahan, yang dibagi menjadi 8 kelas. Kelas I mempunyai pilihan penggunaan yang banyak karena dapat diperuntukan untuk berbagai penggunaan, mulai untuk budidaya intensif hingga tidak intensif, sedangkan kelas VIII, pilihan peruntukannya sangat terbatas, yang dalam hal ini cenderung diperuntukan untuk kawasan lindung atau sejenisnya (Rustiadi et al., 2010).

Menurut Hardjowigeno dan Widiatmaka (2007) dalam tingkat kelas, kemampuan lahan menunjukkan kesamaan dari besarnya faktor-faktor penghambat. Semakin tinggi kelasnya, kualitas lahannya semakin buruk, berarti resiko kerusakan dan besarnya faktor penghambat bertambah dan pilihan penggunaan lahan yang diterapkan semakin terbatas.

\section{Kelas I-VIII}

Lahan kelas I sesuai untuk segala jenis penggunaan pertanian tanpa memerlukan tindakan pengawetan tanah yang khusus. Lahannya datar, solumnya dalam, bertekstur agak halus atau sedang, berdrainase baik, mudah diolah, dan responsif terhadap pemupukan. Lahan kelas I tidak mempunyai penghambat atau ancaman kerusakan, sehingga dapat digarap untuk usaha tani tanaman semusim dengan aman. Tindakan pemupukan dan usaha-usaha pemeliharaan struktur tanah yang baik diperlukan guna menjaga kesuburan dan mempertinggi produktivitas.

Tabel 1. Kriteria Klasifikasi Kemampuan Lahan
Lahan kelas II mempunyai beberapa penghambat yang dapat mengurangi pilihan jenis tanaman yang diusahakan atau memerlukan usaha pengawetan tanah yang tingkatnya sedang.

Lahan kelas III mempunyai penghambat yang agak berat, yang mengurangi pilihan jenis tanaman yang dapat diusahakan, atau memerlukan usaha pengawetan tanah yang khusus, atau keduanya.

Lahan kelas IV mempunyai penghambat yang berat untuk membatasi pilihan tanaman yang dapat diusahakan, memerlukan pengelolaan yang sangat berhatihati, atau kedua-duanya. Penggunaan lahan kelas IV sangat terbatas.

Lahan kelas V mempunyai sedikit atau tanpa bahaya erosi, tetapi mempunyai penghambat lain yang praktis sukar dihilangkan, sehingga dapat membatasi penggunaan lahan ini. Akibatnya, lahan ini hanya cocok untuk tanaman rumput ternak secara permanen atau dihutankan.

Lahan kelas VI mempunyai penghambat yang sangat berat sehingga tidak sesuai untuk pertanian dan hanya sesuai untuk tanaman rumput ternak atau dihutankan. Penggunaan untuk padang rumput harus dijaga agar rumputnya selalu menutup dengan baik. Bila dihutankan, penebangan kayu harus lebih selektif. Bila dipaksakan untuk tanaman semusim, harus dibuat teras bangku. Lahan ini mempunyai penghambat yang sulit sekali diperbaiki.

Lahan kelas VII sama sekali tidak sesuai untuk usaha tani tanaman semusim dan hanya sesuai untuk padang penggembalaan atau dihutankan.

Lahan kelas VIII tidak sesuai untuk produksi pertanian, dan hanya dibiarkan dalam keadaan alami atau dibawah vegetasi hutan. Lahan ini dapat digunakan untuk daerah rekreasi cagar alam atau hutan lindung.

\begin{tabular}{|c|c|c|c|c|c|c|c|c|}
\hline \multirow[b]{2}{*}{ Faktor Penghambat } & \multicolumn{8}{|c|}{ Kelas Kemampuan } \\
\hline & I & II & III & IV & $\mathrm{V}$ & VI & VII & $\overline{\text { VIII }}$ \\
\hline \multicolumn{9}{|l|}{ 1. Tekstur tanah (t) } \\
\hline Lapisan atas $(40 \mathrm{~cm})$ & ah-s & $\mathrm{h}-\mathrm{ak}$ & h-ak & $(+)$ & $(+)$ & $(+)$ & $(+)$ & $\mathrm{k}$ \\
\hline 2. Lereng permukaan (\%) & $0-3$ & $3-8$ & $8-15$ & $15-30$ & $(+)$ & $30-45$ & $45-65$ & $>65$ \\
\hline 3. Drainase & $b-a b$ & $\mathrm{Aj}$ & $\mathrm{j}$ & $\mathrm{Sj}$ & $(++)$ & $(+)$ & $(+)$ & $(+)$ \\
\hline 4. Kedalaman efektif & $>90$ & $>90$ & $90-50$ & $50-25$ & $(+)$ & $<25$ & $(+)$ & $(+)$ \\
\hline 5. Keadaan erosi & $\mathrm{t}$ & $\mathrm{R}$ & $\mathrm{r}$ & $\mathrm{S}$ & $(+)$ & $\mathrm{b}$ & $\mathrm{sb}$ & $(+)$ \\
\hline 6. Kerikil/batuan (\% volume) & $0-15$ & $0-15$ & $0-15$ & $15-50$ & $50-90$ & $(+)$ & $(+)$ & $>90$ \\
\hline 7. Banjir & Oo & Oi & Oii & Oii & Oiv & $(+)$ & $(+)$ & $(+)$ \\
\hline
\end{tabular}


Keterangan: $(+) \quad$ : dapat mempunyai sebarang sifat faktor penghambat dari kelas yang lebih rendah $(++) \quad$ : permukaan tanah selalu tergenang air

Tekstur $\quad$ ah $=$ agak halus; $\mathrm{h}=$ halus; $\mathrm{ak}=$ agak kasar; $\mathrm{k}=$ kasar; $\mathrm{s}=$ sedang

Erosi $\quad: \mathrm{t}=$ tidak ada; $\mathrm{r}=$ ringan; $\mathrm{s}=$ sedang; $\mathrm{b}=$ berat; $\mathrm{sb}=$ sangat berat

Drainase $: \mathrm{b}=$ baik; $\mathrm{ab}=$ agak baik; $\mathrm{aj}=$ agak jelek; $\mathrm{j}=$ jelek; $\mathrm{sj}=$ sangat jelek

Sumber : Konservasi Tanah dan Air (Harjowigeno dan Widiatmaka, 2001).

Pengelompokan tanah ke dalam satuan pengelolaan, subkelas, dan kelas kemampuan dilakukan terutama berdasarkan kemampuan lahan tersebut untuk menghasilkan produksi tanaman jagung tanpa kerusakan tanah di dalam periode waktu yang lama.

\section{Analisis Kesesuian Lahan}

Analisis kesesuaian lahan dilakukan melalui evaluasi lahan untuk mengetahui lahan yang sesuai untuk penggunaan tertentu (Indrianti et al, 2016). Inti evaluasi lahan adalah membandingkan persyaratan yang diminta untuk tipe penggunaan lahan yang akan diterapkan dengan sifat atau kualitas lahan yang dimiliki oleh lahan tersebut. Potensi pengembangan tanaman jagung berdasarkan potensi fisik wilayah dilakukan dengan overlay peta kesesuaian lahan berdasarkan kesesuaian lahan dengan peta Rencana Tata Ruang Wilayah (RTRW) Kabupaten Bone.

\section{Analisis Deskriptif}

Permasalahan yang terjadi dalam pengembangan tanaman jagung di wilayah penelitian diidentifikasi melalui pengamatan langsung dan hasil wawancara mendalam terhadap masyarakat dan stakeholder yang berhubungan langsung. Permasalahan hasil identifikasi tersebut kemudian dianalisis dan dipadukan dengan data hasil analisis sebelumnya sehingga didapatkan strategi peningkatan hasil produksi tanaman jagung yaitu pilot proyek berbasis Korporasi.

\section{HASIL DAN PEMBAHASAN}

\section{Analisis Kemampuan Lahan}

Kemampuan lahan menjelaskan lahan yang mempunyai kemampuan tinggi akan mempunyai pilihan penggunaan yang lebih banyak, baik untuk pertanian atau tujuan lain. Untuk memanfaatkan lahan yang baik, maka diperlukan suatu perencanaan yang baik. Perencanaan ruang biasanya diletakkan dalam peta RTRW. Perencanaan penggunaan ruang yang baik, khususnya untuk kawasan pertanian adalah perencanaan yang berbasis daya dukung lingkungan yang berbasis kemampuan lahan. Berdasarkan hasil olahan data kemampuan lahan, telah teridentifikasi lahan yang sesuai dan tidak sesuai untuk pengembangan pertanian; Selengkapnya lihat Tabel 1

Tabel 1 Luas Kesesuaian Lahan berdasarkan kemampuan lahan untuk lahan pertanian Wilayah Kajian (Ajagale, Amali, Dua Boccoe) Kabupaten Bone.

\begin{tabular}{llllll}
\hline \multirow{2}{*}{ Kecamatan } & \multirow{5}{*}{$\begin{array}{l}\text { Luas } \\
\left(\mathbf{k m}^{2}\right)\end{array}$} & $\begin{array}{l}\text { Kesesuaian Lahan per kecamatan di wilayah Kajian di Kabupaten } \\
\text { Bone berdasarkan kemampuan lahan untuk kawasan pertanian }\end{array}$ \\
\cline { 3 - 6 } & & Sesuai & \multicolumn{2}{c}{ Tidak Sesuai } \\
\cline { 3 - 6 } Ajangale & $\mathbf{1 3 9 . 0 0}$ & $\mathbf{1 3 8}$ & $\mathbf{9 9 . 2 8}$ & $\mathbf{1}$ & $\mathbf{0}$ \\
\hline Amali & 119.13 & 38.57 & 32.37 & 80.57 & $\mathbf{0 . 8 2}$ \\
\hline Dua Boccoe & 144.90 & 139.45 & 96.33 & 5.45 & 3.76 \\
\hline
\end{tabular}

Sumber: Hasil Analisis, 2019

Berdasarkan tabel 1, kesesuaian lahan di lokasi kajian memiliki luasan yang sesuai lebih besar dibandingkan luasan yang tidak sesuai. Selengkapnya lihat pada peta kemampuan lahan pada gambar 1 dan peta analisis kemampuan lahan pada gambar 2 .

Adapun kelas kemampuan lahan yang terdapat di Kecamatan Ajangale yaitu kelas I dan Kelas III dengan faktor penghambat drainase tanah yang buruk (d3). Keadaan ini sudah sejalan dengan pendapat Hardjowigeno dan Widiatmaka (2001 \&
2007) bahwa lahan untuk kelas I, dan II sangat sesuai untuk pengembangan pertanian.

Kelas kemampuan lahan yang ada di Kecamatan Amali yaitu kelas III dengan faktor penghambat yaitu drainase tanah yang buruk (d3), Lereng yang bergelombang (I2, 8-15\%), kedalaman sedang (k1), Erosi Ringan (e1). Selain kelas III, kecamatan amali juga memiliki kelas IV dengan faktor penghambat erosi sedang (e2),lereng berbukit (13,15-30\%) dan kelas VII dengan faktor penghambat erosi sangat berat. Lahan Kelas III sampai kelas VIII, sangat 
tidak sesuai untuk pengembangan pertanian karena lahan tidak produktif. Hal inipun sejalan dengan pernyataan Aziz (2006) dalam Akbar et al (2010), bahwa produktivitas tanaman pangan tergantung

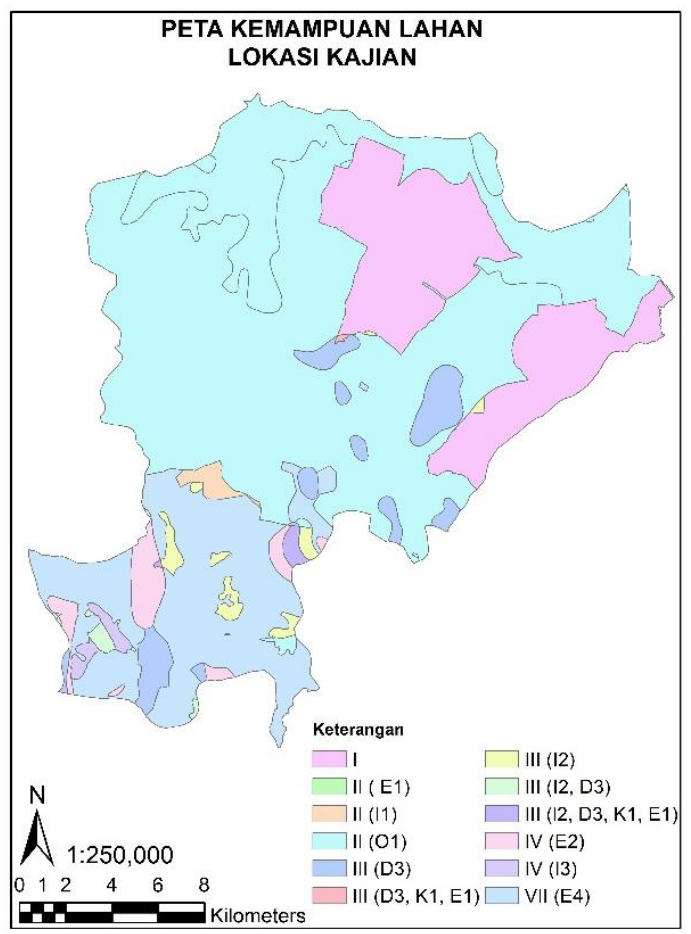

Gambar 1. Peta Kemampuan Lahan pada kualitas lahan yang digunakan. Jika pemilihan lahan yang tidak produktif tidak disisihkan pada awal pengembangan areal tanaman, maka nantinya kerugian (finansial) yang besar akan terjadi.

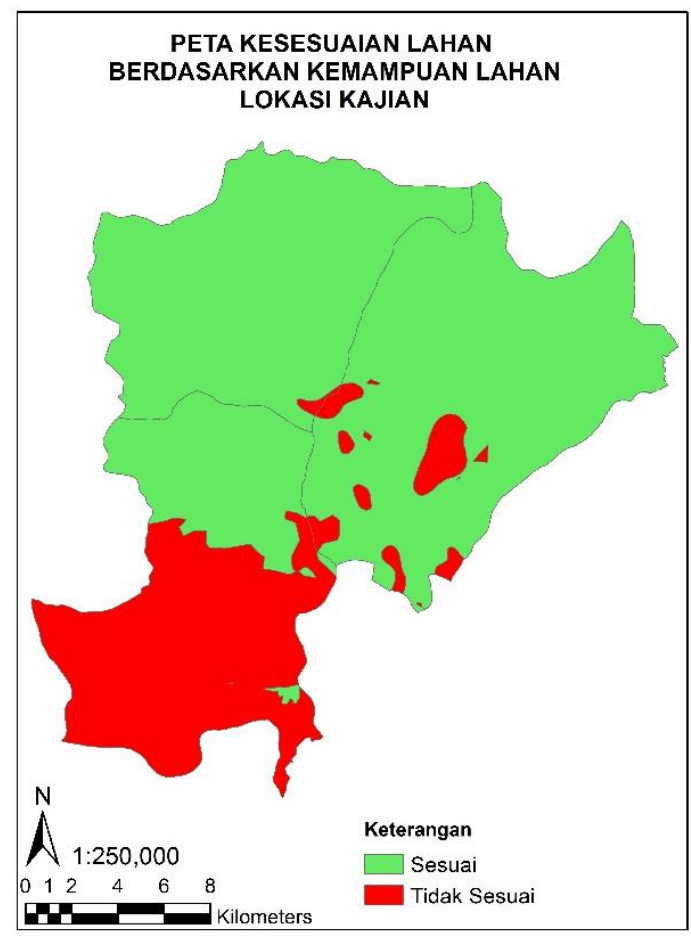

Gambar 2. Peta Analisis Kemampuan Lahan

Analisis kesesuaian lahan pertanian berdasarkana daya dukung lahan (kemampuan lahan) dan rencana pola ruang dalam RTRW Kab Bone

Penggunaan suatu lahan seharusnya sesuai dengan kemampuan lahan. Untuk memanfaatkan lahan yang baik, maka diperlukan suatu perencanaan yang baik. Perencanaan ruang biasanya diletakkan dalam peta RTRW Kabupaten. Perencanaan penggunaan ruang yang baik, khususnya untuk kawasan pertanian adalah perencanaan yang berbasis daya dukung lingkungan yang berarti berbasis kemampuan lahan dan pola ruang (RTRW). Kabupaten Bone. Berdasarkan hasil olahan data kemampuan lahan dan pola ruang, telah teridentifikasi lahan yang sesuai dan tidak sesuai untuk pengembangan pertanian tanaman jagung; Selengkapnya lihat pada peta pola ruang dan peta analisis kesesuaian lahan. Selengkapnya lihat Tabel 2.

Tabel 2 Luas kesesuaian lahan berdasarkan kemampuan lahan dan Rencana Pola Ruang (RTRW) untuk lahan pertanian tanaman jagung di Wilayah Kajian (Ajagale, Amali, Dua Boccoe) Kabupaten Bone.

\section{Kesesuaian Lahan}

\begin{tabular}{lccccc}
\multirow{2}{*}{ Kecamatan } & \multirow{2}{*}{\begin{tabular}{c} 
Luas \\
\cline { 3 - 6 }
\end{tabular}} & & \multicolumn{2}{c}{ Sesuai } & \multicolumn{2}{c}{ Tidak Sesuai } \\
\cline { 3 - 6 } & & Luas $\left(\mathbf{k m}^{2}\right)$ & \% & Luas $\left(\mathbf{k m}^{\mathbf{2}}\right)$ & \% \\
\hline Ajangale & $\mathbf{1 3 9 . 0 0}$ & $\mathbf{1 3 3 . 2 4}$ & $\mathbf{9 5 . 8 6}$ & $\mathbf{5 . 7 6}$ & $\mathbf{4 . 1 4}$ \\
\hline Amali & 119.13 & 30.93 & 25.96 & 88.20 & 74.04 \\
\hline Dua Boccoe & 144.90 & 129.03 & 89.05 & 15.87 & 10.95 \\
\hline
\end{tabular}

Sumber: Hasil Analisis, 2019

Berdasarkan tabel 1, kesesuaian lahan di lokasi kajian memiliki luasan yang sesuai lebih besar dibandingkan luasan yang tidak sesuai. Selengkapnya lihat pada peta kemampuan lahan dan peta analisis kemampuan lahan. Adapun faktor penghambat untuk kesesuaian lahan berdasarkan kemampuan lahan dan pola ruang (RTRW) yaitu Kawasan Budidaya (lahan terbangun dan 
permukiman). Selengkapnya lihat pada peta rencana pola ruang (RTRW) Kabupaten Bone pada gambar 3 dan peta analisis kesesuaian lahan pada gambar 4.

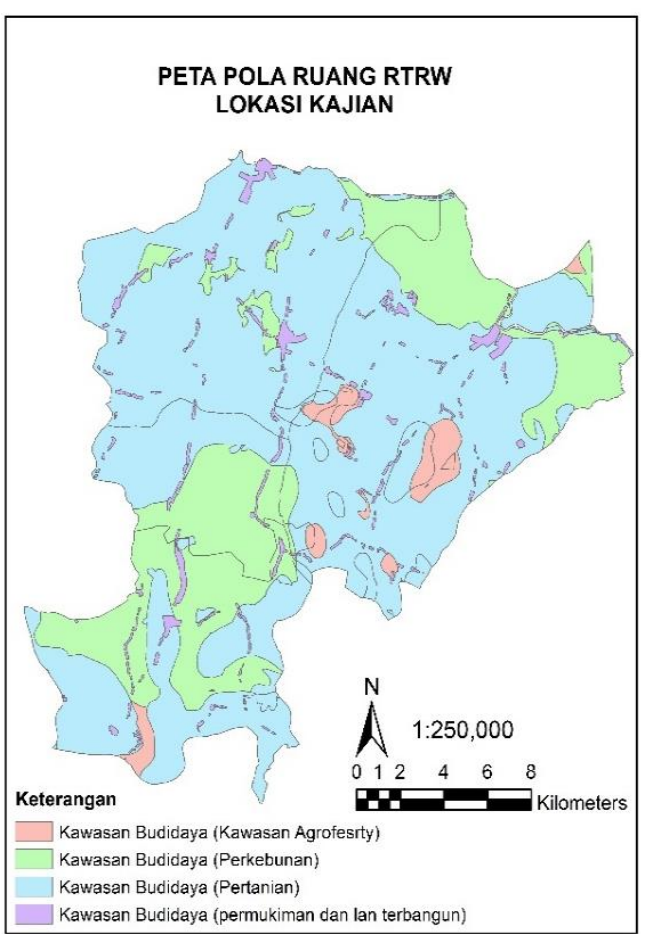

Gambar 3. Peta Pola Ruang (RTRW)

Strategi peningkatan hasil produksi tanaman jagung dengan cara pilot project berbasis korporasi.

Menurut Setiawan (2014), pilot proyek merupakan uji coba implementasi sistem terkait pengembangan sistem informasi yang baru dengan metode percontohan. Peningkatan hasil produksi tanaman jagung dengan sistem pilot proyek berbasis korporasi sangat baik dilakukan untuk kesejahteran petani. Dalam menginisiasi pembentukan kelembagaan petani menjadi kelembagaan korporasi petani, ditopang oleh sekurangkurangnya 5 (lima) aspek utama mencakup: 1) konsolidasi Petani ke dalam Kelembagaan Ekonomi Petani berbadan hukum; 2) aksesibilitas terhadap fasilitas infrastruktur publik; 3) aksesibilitas terhadap sarana pertanian modern; 4) konektivitas dengan mitra industri pengolahan dan perdagangan modern; dan 5) aksesibilitas terhadap permodalan dan asuransi. Kelima aspek tersebut digambarkan sebagai satu kesatuan yang menopang keberlanjutan kelembagaan Korporasi Petani (Kementerian Pertanian, 2018).

1. Konsolidasi Petani

Karakteristik umum pertanian rakyat yang berskala kecil, tersebar dan terfokus di on farm, mengakibatkan Usaha Tani tidak efisien dan cenderung subsisten. Produk yang dihasilkan Petani umumnya memiliki jenis dan mutu yang tidak

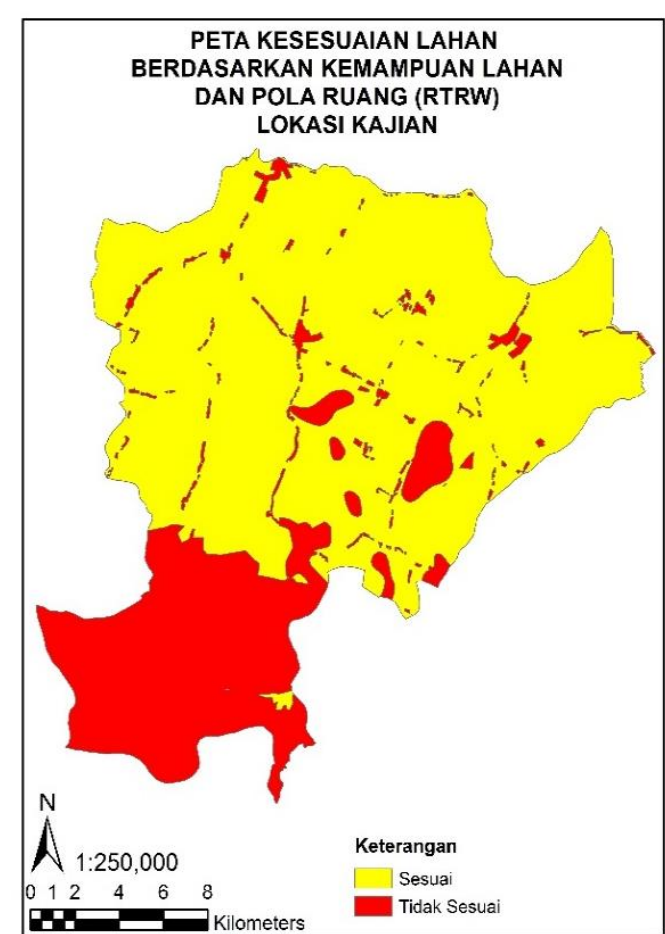

Gambar 4. Peta Kesesuaian Lahan

seragam, serta manajemen usaha yang masih tradisional. Oleh karena itu, diperlukan upaya untuk mengkonsolidasikan Petani agar mampu memperoleh berbagai efisiensi dalam mendapatkan sarana produksi dan memasarkan produk, sehingga Kelembagaan Petani yang masih terfokus di on farm dapat bertransformasi menjadi Kelembagaan Ekonomi Petani berbadan hukum yang terintegrasi dalam suatu lembaga Korporasi Petani. Gabungan Kelompok Tani yang telah terkonsolidasi dapat berintegrasi atau membentuk Kelembagaan Ekonomi Petani berbadan hukum berupa koperasi atau badan usaha lain sesuai dengan ketentuan peraturan perundang-undangan, sehingga dapat bermitra dengan perusahaan yang bergerak di bidang industri pengolahan atau perdagangan. Konsolidasi petani diawali dengan mengidentifikasi Gabungan Kelompok Tani yang memiliki kesamaan komoditas dan spesialisasi jenis produk. Melalui konsolidasi Petani ke dalam kelembagaan korporasi, akan terbentuk Kelembagaan Ekonomi Petani berbadan hukum yang terorganisir dan memiliki kesamaan tujuan usaha. Dengan demikian, petani tidak hanya berperan sebagai produsen bahan mentah, tetapi juga mampu berperan sebagai penyedia bahan baku atau bahan setengah jadi yang dibutuhkan perusahaan industri pengolahan secara berkesinambungan. Dengan demikian, Petani terlibat secara aktif sebagai pelaku pasar, sehingga 
memperkuat posisi tawar petani (bargaining position) terutama dalam penetapan harga dan penetapan standar kualitas.

2. Aksesibilitas terhadap Fasilitas Infrastruktur Publik

Pengembangan kawasan yang berbasis korporasi tidak dapat berjalan dengan baik apabila akses terhadap fasilitas infrastruktur publik tidak terpenuhi sesuai kebutuhan skala kawasan. Kelembagaan Ekonomi Petani berbadan hukum yang terbentuk dalam skala kawasan akan lebih membuka peluang untuk mendapatkan kemudahan akses terhadap infrastruktur publik, terutama pengairan dan prasarana transportasi, infrastruktur jalan, komunikasi dan energi, sehingga akan memiliki posisi tawar yang lebih tinggi untuk mengusulkan kepada pemerintah agar menyediakan infrastruktur publik dibutuhkan. Di samping itu, Kelembagaan Ekonomi Petani berbadan hukum yang terbentuk dalam skala kawasan, mampu secara swadaya membiayai pengadaan dan/atau pemeliharaan sebagian fasilitas infrastruktur publik yang belum tersedia.

3. Aksesibilitas terhadap Sarana Pertanian Modern

Skala kepemilikan usaha individu Petani yang relatif kecil tidak efisien apabila menggunakan alat dan mesin pertanian modern yang harganya relative mahal. Melalui Kelembagaan Ekonomi Petani berbadan hukum, kepemilikan alat dan mesin pertanian modern dimungkinkan untuk digunakan secara bersama yang biaya pengadaan dan operasionalnya relatif lebih murah. Alat dan mesin pertanian seperti traktor besar, transplanter multiguna, combine harvester, rumah pengering, warehouse, dan cold storage membutuhkan biaya pengadaan, operasional serta pemeliharaan yang relatif mahal, namun dimungkinkan apabila dimiliki dan dikelola oleh Kelembagaan Ekonomi Petani berbadan hukum. Di samping itu, pengadaan sarana produksi seperti bibit, benih, pupuk, pestisida dan obat-obatan serta sarana lainnya dapat diperoleh dengan harga yang lebih murah apabila dikelola oleh Kelembagaan Ekonomi Petani berbadan hukum.

4. Konektivitas dengan Mitra Industri

Pengolahan dan Perdagangan Modern

Interaksi antara Korporasi Petanidengan kelembagaan usaha ekonomi lainnya dapat meningkatkan aksesibilitas Petani ke pasar dan sumber pembiayaan. Korporasi antara kelompok usaha industri atau perdagangan dengan Korporasi Petani, dapat memfasilitasi kebutuhan sarana produksi dalam bentuk tunai atau natura yang dikelola oleh Kelembagaan Ekonomi Petani berbadan hukum sebagai bentuk pinjaman modal.

5. Aksesibilitas terhadap Permodalan dan Asuransi

Sulitnya individu Petani untuk mengakses sumber pembiayaan dalam bentuk kredit program atau kredit komersial lainnya, selain disebabkan oleh ketiadaan agunan juga disebabkan oleh besarnya risiko Usaha Tani seperti gagal panen atau fluktuasi harga. Usaha Tani yang dikelola oleh
Kelembagaan Ekonomi Petani berbadan hukum dapat lebih menjamin: 1) kelayakan skala usaha; 2) peningkatan produktivitas budidaya; 3) dampak gejolak harga melalui perencanaan pola dan pengaturan jadwal tanam/panen; serta 4) pemilihan jenis dan pengaturan mutu produk yang bernilai tambah lebih tinggi. Dengan demikian, dapat menekan risiko kegagalan Usaha Tani, sehingga lebih menarik bagi lembaga pembiayaan untuk meminjamkan modal usaha.

Di samping itu, Korporasi Petani yang dikelola dalam skala kawasan dapat lebih menarik bagi sumber pembiayaan yang berasal dari kementerian/lembaga yang membidangi pengembangan usaha kecil dan menengah; perindustrian dan perdagangan; lembaga keuangan perbankan maupun nonperbankan; serta swasta diantaranya melalui dana Corporate Social Responsibilty (CSR). Asuransi Usaha Tani secara mandiri akan lebih mudah dirintis melalui Kelembagaan Ekonomi Petani berbadan hukum, karena lebih meningkatkan kepercayaan lembaga asuransi dalam memberikan penjaminan.

\section{SIMPULAN}

Berdasarkan hasil penelitian tersebut dapat disimpulan sebagai berikut: (1) Terdapat 42 wilayah desa yang sesuai untuk perencanaan pengembangan tanaman jagung yaitu Allamugeng patue, ammessangeng, labissa, lebbae, leppangeng, manciri, opo, pacciro, pinceng pute, pompanua, pompanua riattang, telle, timurung, welado, ajang laleng, benteng tellue, laponrang, mattaro purae, tassipi, wellulang. cabbeng, kampoti, laccori, lallatang, mario, matajang, melle, padacenga, pakkasalo, panyili, pattiro, praja maju, sailong, sanrangeng, solo, tawaroe, tempe, tocina, ujung, uloe, unnyi dan watang padacenga. Sedangkan 9 desa yang tidak sesuai sama sekali untuk perencanaan pengembangan tanaman jagung yaitu amaliriattang, benteng tellue, bila, lili riattang, mampotu, taccipong, ulaweng riaja, waempubbue dan waemputtange; (2) Strategi peningkatan hasil produksi tanaman jagung dengan cara pilot project berbasis korporasi petani.

\section{DAFTAR PUSTAKA}

Akbar., Baba barus, Dwi Putri tejo Baskoro. (2014). Pengembangan Komoditas Unggulan Tanaman Pangan di Kabupaten Bone. Jurnal Tata Loka, 16(2): 94-107.

Bahtiar., S.Pakki., Zubachtirodin. (2007). Sistem Perbenihan Jagung. Jagung Teknik produksi dan Pengembangan. Pusat Penelitian dan Pengembangan Tanaman Pangan, Departemen Pertanian. Maros: EGC. 177-191. 
[BPS] Badan Pusat Statistik Kabupaten Bone (2018). Bone dalam angka 2018. Bone. BPS Kabupaten Bone.

[KP] Kementerian Pertanian. 2018. Peraturan Menteri Pertanian Republik Indonesia Nomor

18/PERMENTAN/RC.040/4/2018

tentang Pedoman Pengembangan Kawasan Pertanian Berbasis Korporasi Petani. Jakarta (ID): KP.

Handayani, D., Soelistijasi, S., \& Sunardi. (2005). Pemanfaatan analisis spasial untuk pengolahan data spasial sistem informasi geografis, studi kasus Kabupaten Pemalang. Jurnal Teknologi Informasi Dinamik, 10(2): 108-116.

Hardjowigeno S, Widiatmaka. 2001. Kesesuaian Lahan dan Perencanaan Tata Guna Tanah. Bogor: Jurusan Tanah, Fakultas Pertanian, Institut Pertanian Bogor.

Hardjowigeno S, Widiatmaka. 2007. Evaluasi Kesesuaian Lahan dan Perencanaan Tata Guna Lahan. Yogyakarta: Gadjah Mada University Press.

Merita Ayu Indrianti, Nelson Pomalingo, Muh Hatta Jamil. (2016). Pengembangan Komoditas Unggulan Tanaman Pangan di Kabupaten Bone Bolango. Jurnal Sains dan Teknologi, 16(3): 203-209.

Rustiadi E, Saefulhakim S, Panuju DR. (2011). Perencanaan dan Pengembangan Wilayah. Jakarta (ID): Crestpent Press dan Yayasan Pustaka Obor.

Setiawan C dan Emirsa E S. (2014). Analisis Kebijakan Terkait Prioritas Pilot Project Implementasi Sistem Informasi Menggunakan Analytical Hierarchy Process. Pekomnas.17 (3):129-138.

Sumarni Panikkai. 2017. Model Pengembangan Produksi Jagung untuk Memenuhi Kebutuhan Industri dan Peningkatan Perekonomian. [Disertasi]. Bogor (ID): Institut Pertanian Bogor. 